estimate because larger grain sizes are increasingly resistant to deformation. Although it is possible for large crystals to grow in the deepest part of the inner core, this would confine the viscous flow to the outermost region. Low geodynamic bounds on the viscosity of a layer imply much smaller grain sizes in this region. For example, a grain size of $0.5 \mathrm{~mm}$ or less is required, if the flow is confined to a $100-\mathrm{km}$-deep layer.

A complementary estimate of viscosity is deduced by assuming that the mechanism responsible for viscous creep is also responsible for shear attenuation of seismic waves ${ }^{14,18}$. If the inner core behaves like a Maxwell solid, then we find that a quality factor $Q_{\mu}$ of roughly 100 for low-frequency free oscillations ${ }^{19}$ implies a viscosity of $10^{15} \mathrm{Pas}$. This value is a lower bound because all of the seismic attenuation is attributed to the creep mechanism. By contrast, the low-viscosity estimate of $3 \times 10^{16} \mathrm{~Pa}$ s can be viewed as an upper bound for the preferred mode of adjustment. These two estimates are mutually consistent, but the common range of viscosity is remarkably narrow.

Geodynamic estimates of inner-core viscosity are important for several purposes. Dynamical processes such as thermal convection ${ }^{20}$ and viscous compaction ${ }^{21}$ are strongly influenced by the value of viscosity. Moreover, the small grain sizes implied by such estimates yield insights into crystal growth in the inner core. Restrictions on the growth of iron grains may point to the importance of deformational stresses or chemical impurities. Small grain sizes and low viscosities also have important consequences for the source of seismic anisotropy in the inner core. Persistent deformation of the inner core owing to its rotation relative to the mantle does not favour the high degree of crystal alignment that is needed in the high-pressure (hexagonal close-packed) phase of iron to explain the anisotropy ${ }^{17}$. A search for alternative explanations of the anisotropy is thus required. Unravelling the clues left behind by the growth of the inner core offers the hope of new insights into the evolution of the Earth's deep interior.

Received 31 January; accepted 1 July 1997.

1. Song, X. \& Richards, P. Seismological evidence for the rotation of the Earth's inner core. Nature 382 221-224 (1996)

2. Su, W.-J., Dziewonski, A. M. \& Jeanloz, R. Planet within a planet: rotation of the inner core of the Earth. Science 274, 1883-1887 (1996).

. Glatzmaier, G. \& Roberts, P. H. Rotation and magnetism of Earth's inner core. Science 274, 1887-1891 (1996).

4. Buffett, B. A. A mechanism for decade fluctuations in the length of day. Geophys. Res. Lett. 23, 3803 3806 (1996).

Creager, K. C. Anisotropy of the inner core from differential travel times of phases PKP and PKIKP. Nature 356, 309-314 (1992).

6. Song, X. \& Helmberger, D. V. Depth dependence of anisotropy of Earth's inner core. J. Geophys. Res. 100, 9805-9816 (1995).

Su, W.-J. \& Dziewonski, A. M. Inner core anisotropy in three dimensions. J. Geophys. Res. 100, $9831-$ 9852 (1995).

8. Glatzmaier, G. \& Roberts, P. H. An anelastic evolutionary geodynamo simulation driven by compositional and thermal convection. Physica D 97, 81-94 (1996).

9. Aurnou, J. M., Brito, M. \& Olson, P. L. Mechanics of inner core super-rotation. Geophys. Res. Lett. 23 3401-3404 (1996).

10. Forte, A. \& Peltier, W. R. Viscous flow models of global geophysical observables, 1 Forward problems J. Geophys. Res. 99, 21857-21877 (1991).

11. Edmonds, A. R. Angular Momentum in Quantum Mechanics (Princeton Univ. Press, 1960)

12. Hager, B. H. \& Clayton, R. W. in Mantle Conveciton (Gordon \& Breach, New York, 1989).

13. Loper, D. E. \& Roberts, P. H. A study of conditions at the inner core boundary of the Earth. Phys. Earth Planet. Inter. 24, 302-307 (1981)

14. Yoshida, S., Sumita, I. \& Kumazawa, M. Growth model of the inner core coupled with outer core dynamics and the resulting elastic anisotropy. J. Geophys. Res. 101, 2805-28103 (1996).

15. Poirier, J.-P. Creep of Crystals: High-temperature Deformation Processes in Metals, Ceramics, and Minerals (Cambridge Univ. Press, 1985).

16. Frost, H. J. \& Ashby, M. F. Deformation Mechanism Maps Ch. 4 (Pergamon, Oxford, 1983).

17. Stixrude, L. \& Cohen, R. E. High-pressure elasticity of iron and anisotropy of Earth's inner core. Science 267, 1972-1975 (1995).

18. Anderson, D. L. Earth's viscosity. Science 151, 321-322 (1966).

19. Widmer, R., Masters, G. \& Gilbert, F. Spherically symmetric attenuation within the Earth from normal mode data. Geophys. J. Int. 104, 541-553 (1991).

20. Jeanloz, R. \& Wenk, H.-R. Convection and anisotropy of the inner core. Geophys. Res. Lett. 15, 72-75 (1988).

21. Sumita, I., Yoshida, S., Kumazawa, M. \& Hamano, Y. A model for sedimentary compaction of a viscous medium and its application to inner-core growth. Geophys. J. Int. 124, 502-524 (1996).

Acknowledgements. I thank J. Bloxham, B. Hager, P. Richards and D. Stevenson for comments and suggestions. J. Bloxham and D. Stevenson independently suggested the possibility of the high-viscosity solution. This work was supported by NSERC.

Correspondence and requests for materials should be addressed to the author (e-mail: buffett@geop.ubc.ca).

\section{Deep marine biosphere fuelled by increasing organic matter availability during burial and heating}

\section{Peter Wellsbury, Kim Goodman, Tanja Barth*, Barry A. Cragg, Stephen P. Barnes \& R. John Parkes}

Department of Geology, University of Bristol, Wills Memorial Building,

Queens Road, Bristol BS8 1RJ, UK

* Department of Chemistry, University of Bergen, Allegt. 41, N-5007 Bergen, Norway

Deep-sea sediments become apparently more hostile to life with increasing depth as temperature and pressure rise, and organic matter becomes increasingly recalcitrant. Demonstrations of high bacterial populations in deep sediments ${ }^{1,2}$ may thus appear enigmatic. How, then, can the continued presence of active bacterial populations in deep sediments that are over 10 million years old be explained? Although volatile fatty acids, particularly acetate, are important intermediates in the anaerobic degradation of organic matter ${ }^{3,4}$, their concentrations are kept very low in sediments $(<15 \mu M)$ by rapid bacterial consumption ${ }^{5,6}$. Here we show that heating surface coastal marine sediments to simulate increasing temperature during burial produces an increase of over three orders of magnitude in acetate concentration and increases bacterial activity. We found that pore-water acetate concentration at two sites in the Atlantic Ocean increased at depths below about $150 \mathrm{~m}$ and was associated with a significant stimulation in bacterial activity. Comparing these acetate concentrations to in situ temperatures confirmed that there was a notable generation of acetate associated with temperature increases during burial. This was supported by heating experiments with deep sediments. Thus, acetate generation from organic matter during burial may explain the presence of a deep bacterial biosphere in marine sediments, and could underpin an even deeper and hotter biosphere than has previously been considered.

In anaerobic marine sediments, volatile fatty acids (VFA) can reflect the intensity and route of organic matter degradation, as they are important metabolic intermediates in anaerobic bacterial metabolism ${ }^{3,4}$. The most important is acetate, which accounts for $>60 \%$ of sulphate reduction ${ }^{4}$, the dominant anaerobic process in marine sediments ${ }^{5}$. Closely coupled production and consumption of acetate in near-surface sediments keeps pore-water concentrations very low ( $<15 \mu \mathrm{M}$; ref. 6$)$; in deeper sediments, even lower acetate concentrations would be expected. This is reinforced by the observation that bacterial methane production, which occurs deeper than sulphate reduction in marine sediments, is predominantly from $\mathrm{H}_{2}$ and $\mathrm{CO}_{2}$ rather than acetate ${ }^{7}$. However, VFA are known to exist at high concentrations in deep oil-reservoir-formation waters, considered to be due to abiological organic matter cracking at temperatures above $80^{\circ} \mathrm{C}^{8,9}$.

In heating experiments $\left(0-100^{\circ} \mathrm{C}\right)$ with surface coastal marine sediments, we investigated the possibility of acetate being generated from organic matter as a result of the increasing thermal gradient during sediment burial (Fig. 1), and within the temperature range for bacterial activity. After only 7 days, notable amounts of acetate $(24,000 \mu \mathrm{M})$ were produced between 10 and $60^{\circ} \mathrm{C}$ (temperature range within that for meso- and thermophilic bacteria) compared to the in situ concentration of $12 \mu \mathrm{M}$. This production is considered to be bacterial, as little acetate was produced at temperatures $>60{ }^{\circ} \mathrm{C}$, and acetate concentrations reflected a typical bacterial growth curve with increasing temperature. This acetate was simultaneously being 


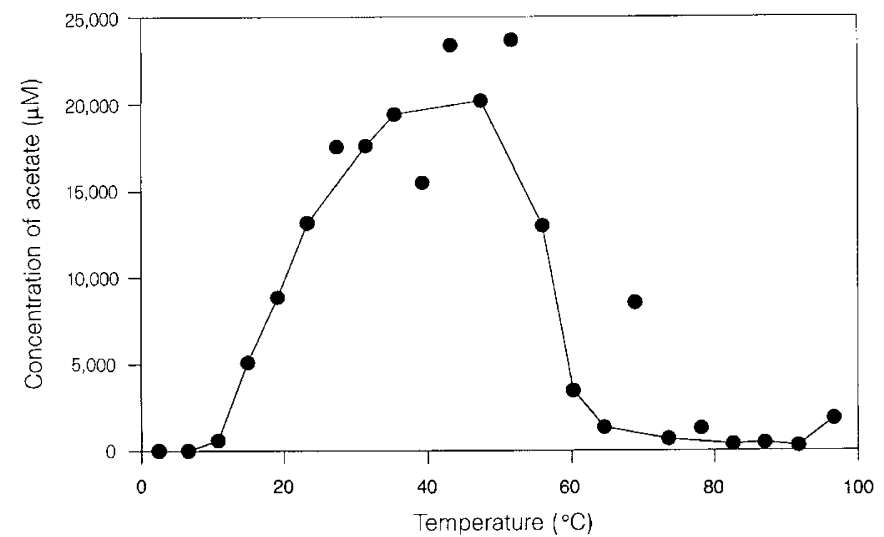

Figure 1 Generation of pore-water acetate from a coastal near-surface sediment exposed to low-temperature heating. Material taken from the uppermost $1 \mathrm{~cm}$ of an intertidal mudflat at Southdown, Tamar Estuary, UK, was slurried (25\% v/v) with sterile anoxic artificial seawater and incubated in a thermal gradient system ${ }^{28}$ for 7 days. Pore-water acetate concentrations were determined by enzymatic high-pressure liquid chromatography (HPLC) $)^{11}$. Active sulphate reduction occurred during incubation; as acetate is the principal substrate for this activity ${ }^{21}$ in the Tamar Estuary, acetate concentrations were compensated for acetate consumption based on the amount of sulphate removed, and dilution due to slurrying.

used as an energy source by sulphate-reducing bacteria ( $92 \%$ of acetate production was consumed).

As a consequence of these results, concentrations of pore-water acetate were determined in deeper sediments than had been previously analysed ${ }^{10}$ to investigate the effect of temperature increases during burial (Blake Ridge, Atlantic Ocean, ODP Leg 164, Site 995; Fig. 2). Although near-surface concentrations were within the expected low range $(7 \mu \mathrm{M}$ at $0.5 \mathrm{~m})$ and remained close to these levels to $82.5 \mathrm{~m}$, acetate concentrations began to increase $(68 \mu \mathrm{M}$ at $154 \mathrm{~m})$ in deeper sediment and continued to increase with increasing depth. Concentrations reached $15,285 \mu \mathrm{M}$ at $691 \mathrm{~m}$, an increase of over three orders of magnitude (2,248 times). These measurements were confirmed by two independent techniques; ion chromatography and a specific enzymatic technique. The enzymatic technique determines acetate in a biologically available form ${ }^{6,11}$, and indeed some of this acetate is being metabolized in the deep sediments. For example, methanogenesis from acetate below about $400 \mathrm{~m}$ was an order of magnitude greater than the maximum surface rate $\left(1,240 \mathrm{nmol} \mathrm{ml}^{-1}\right.$ day $^{-1}$ at $599 \mathrm{~m}, 183 \mathrm{nmol} \mathrm{ml}^{-1}$ day $^{-1}$ at $1.65 \mathrm{~m}$, respectively). Acetate oxidation to $\mathrm{CO}_{2}$ was stimulated to an even greater extent (Fig. 2). Below about $400 \mathrm{~m}$, increases in other VFA were also detected.

Bacterial processes are complicated in these deeper sediments by the presence of methane hydrate between $445 \mathrm{~m}$ (base of bottomsimulating reflector) and $190 \mathrm{~m}$ (top of hydrate stability field ${ }^{12}$. Previous research has demonstrated that deep bacterial populations are stimulated within methane hydrate zones ${ }^{2}$ and this is also evident at Blake Ridge (Fig. 2). Generally, a range of bacterial activities (methanogenesis from carbon dioxide ${ }^{13}$, methanogenesis from acetate ${ }^{6}$, methane oxidation ${ }^{13}$ ) and bacterial growth (thymidine incorporation ${ }^{14}$ ) are stimulated around the hydrate (370 to $500 \mathrm{~m}$ ) and this results in a significant increase in bacterial populations (to $5.6 \times 10^{7}$ cells per $\mathrm{ml}$ ). In deeper layers, where acetate increases further, methane production from acetate, acetate mineralization and methane oxidation continue to increase. Methane production from acetate, however, is much greater than methane

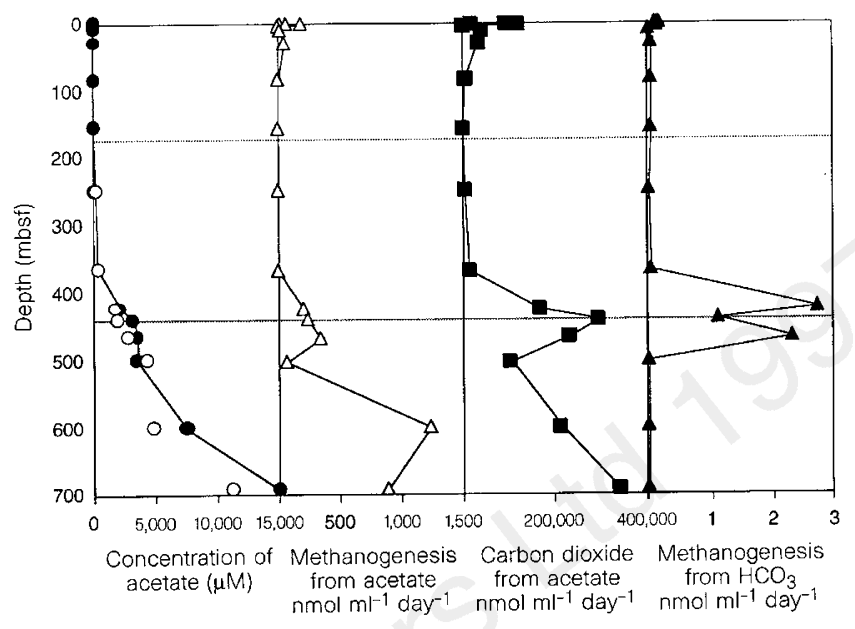

Figure 2 Depth profiles of pore-water acetate concentrations and rates of bacterial activity in sediments from Blake Ridge, ODP Leg 164, Site 995. Acetate determinations were performed on filter-sterilized $(0.1 \mu \mathrm{m})$ pore-water samples by enzymatic HPLC ${ }^{11}$ (filled circles) and ion-exclusion chromatography ${ }^{29}$ (empty circles). Rates of methane production from bicarbonate (filled triangles) and acetate (empty triangles), and acetate oxidation to $\mathrm{CO}_{2}$ (squares) were determined using $\mathrm{H}^{14} \mathrm{CO}_{3}$ - and $\left[1-(2)^{14} \mathrm{C}\right]$ acetate, respectively, as radiotracers, injected into subcores of sediment and incubated for a range of time periods before determination of ${ }^{14} \mathrm{CH}_{4}$ and ${ }^{14} \mathrm{CO}_{2}{ }^{6,13}$. Dotted lines indicate the upper and lower (bottom-simulating reflector) boundaries of the gas hydrate stability field.

oxidation, which is consistent with increased methane concentrations at depth ${ }^{12}$.

When plotted against temperature ${ }^{15}$, rather than depth, Site 995 pore-water acetate concentrations show a remarkable similarity to the acetate generated by heating coastal marine sediments (Fig. 3). In addition, the pore-water acetate depth profile (determined by isotachophoresis ${ }^{16}$ ) from another site (997) on the Blake Ridge was similar to that of Site 995 . Any disparity was probably the result of differences in the thermal gradient at the sites $\left(32\right.$ and $37^{\circ} \mathrm{C} \mathrm{km}^{-1}$ at 995 and 997, respectively ${ }^{15}$ ) because, when plotted against temperature, the acetate concentrations at the two sites are identical (not significantly different at $P>0.01$ ). This demonstrates that deepsourced acetate may be a general feature of marine sediments and that generation is closely coupled to increased temperature during burial. Heating even more deeply buried sediments to much higher temperatures (such as Kimmeridge Clay at $250-350{ }^{\circ} \mathrm{C}$ ) releases further acetate $\left(5.7-18.9 \mathrm{mmol} \mathrm{kg}^{-1} \mathrm{rock}^{8}\right)$ through abiological mechanisms, providing a potential for continued acetate generation throughout sediment burial. As bacteria can grow up to about $113^{\circ} \mathrm{C}$, and possibly even higher ${ }^{17,18}$, acetate generation from organic matter potentially provides an energy source for a deep hot biosphere ${ }^{19}$.

If this theory of low-temperature acetate generation during organic matter burial is correct, then one would expect that deeper sediments, already subjected to increased temperatures and some acetate production, would generate less acetate on further heating compared to a near-surface sediment. To test this, we heated sediments from different depths $(0.13,365,690 \mathrm{~m})$ from the same site (995; Blake Ridge), for which the pore-water profiles were obtained, together with near-surface samples from a Pacific Ocean ODP site (Leg 146, Cascadia Margin). After only 7 days incubation of Blake Ridge sediments, considerable acetate was generated, and after 21 days (Fig. 4) the amounts of acetate produced were similar to the concentrations present in deep sediment pore-water (Fig. 2), although, unsurprisingly, somewhat lower than those produced on heating coastal sediments, which contain highly labile organic 


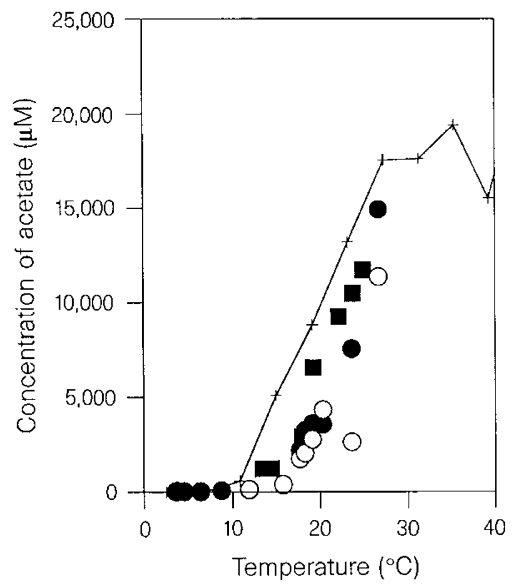

Figure 3 Comparison of in situ pore-water acetate concentrations from Blake Ridge sediments with experimental low-temperature acetate generation from near-surface coastal sediments. Site 995 was determined by enzymatic HPLC ${ }^{11}$ (filled circles) and ion-exclusion chromatography ${ }^{29}$ (empty circles), and Site 997 (squares) by isotachophoresis ${ }^{16}$. For comparison, the solid line is taken from the surface sediment heating experiments shown in Fig. 1.

matter (Fig. 1). Acetate generation decreased, as expected, with increasing depth. In addition, generation from the deepest sample $(690 \mathrm{~m})$ required a much higher temperature $\left(55^{\circ} \mathrm{C}\right)$ compared to the near-surface sample $(0.13 \mathrm{~m})$, where maximal acetate generation occurred at $30^{\circ} \mathrm{C}$. Generation at $365 \mathrm{~m}$ was intermediate between these two. Acetate production also occurred in heated near-surface Pacific Ocean sediments from the Cascadia Margin (acetate concentration increased from $13 \mu \mathrm{M}$ to $1,087 \mu \mathrm{M}$ after 22 days at $\left.30^{\circ} \mathrm{C}\right)$.

Methane production from acetate in deep sediments should be reflected in the isotope composition of methane gas, and $\delta^{13} \mathrm{C}$ values confirm $\mathrm{CH}_{4}$ in the Blake Ridge to be biogenic ${ }^{20}$. However, based on a combination of $\delta^{13} \mathrm{C}$ and $\delta \mathrm{D}$ values, the bulk of biogenic methane in marine sediments has been considered to originate from $\mathrm{H}_{2}: \mathrm{CO}_{2}$ rather than acetate ${ }^{7}$. Other sources of $\mathrm{CH}_{4}$ in marine sediments have been ascribed to abiological thermogenic processes; such methane, although it has a similar $\delta^{13} \mathrm{C}$ value to acetate methanogenesis $(-50 \%)$, may be discriminated on the basis of its $\delta \mathrm{D}$ (thermogenic $<-250 \%$, acetate $>-250 \%$; ref. 7). Recent evidence ${ }^{21}$ has shown, however, that there is significant deuterium exchange during acetate methanogenesis. Hence, $\delta \mathrm{D}$ values may not always be an effective means of distinguishing between abiological thermogenic and biological acetoclastic methanogenesis. Therefore, it is possible that acetoclastic $\mathrm{CH}_{4}$ generation in deep marine sediments has previously been underestimated.

Our results demonstrate that relatively low-temperature heating during burial increases the bioavailability of sedimentary organic matter and this is reflected in marked increases in pore-water acetate concentrations. This process would continue during burial and, together with acetate consumption, provides a bacterial energy source that continues to increase with depth and would explain the presence of the significant bacterial populations now known to be widespread in deep marine sediments ${ }^{1,2,18,22-26}$. These results also offer the prospect of viable bacterial populations being present in marine sediments much deeper than the deepest samples currently analysed (750 m; ref. 27). As temperature increases in even deeper sediments, high-temperature bacteria may develop (thermophiles and hyperthermophiles, 45 to $113^{\circ} \mathrm{C}^{17}$ ). These prokaryotes could continue to exploit buried organic matter made more bioavailable owing to heating, even into the oil window $\left(100\right.$ to $\left.150^{\circ} \mathrm{C}\right)$. Hence,

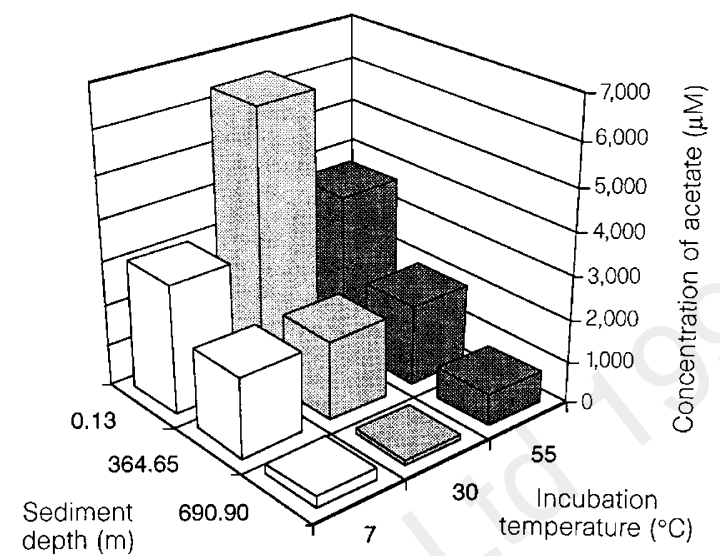

Figure 4 Generation of acetate from deep-sediment samples subjected to lowtemperature heating. Sediment from ODP Leg 164, site 995 (Blake Ridge, 0.13, 365 and $690 \mathrm{~m}$ depth), was slurried with sterile, anoxic mineral salts solution and incubated for 22 days before pore-water extraction by centrifugation under nitrogen and determination of pore-water acetate concentrations by enzymatic HPLC ${ }^{11}$. To enable comparison with in situ profiles, acetate concentrations were adjusted for dilution during slurrying.

deep sediment bacteria may play a role in organic matter maturation, a prelude to oil and gas generation.

Received 19 May; accepted 19 June 1997

1. Parkes, R. J. et al. Deep bacterial biosphere in Pacific Ocean sediments. Nature 371, 410-413 (1994).

2. Cragg, B. A. et al. Bacterial populations and processes in sediments containing gas hydrates (ODP Leg 146: Cascadia Margin). Earth Planet. Sci. Lett. 139, 497-507 (1996).

3. Sørensen, J., Christensen, D. \& Jørgensen, B. B. Volatile fatty acids and hydrogen as substrates for sulfate-reducing bacteria in anaerobic marine sediment. Appl. Environ. Microbiol. 42, 5-11 (1981).

4. Winfrey, M. R. \& Ward, D. M. Substrates for sulfate reduction and methane production in intertidal sediments. Appl. Environ. Microbiol. 45, 193-199 (1983).]

5. Jørgensen, B. B. Mineralisation of organic matter in the sea bed: The role of sulphate reduction. Nature 296, 643-645 (1982).

6. Wellsbury, P. \& Parkes, R. J. Acetate bioavailability and turnover in an estuarine sediment. FEMS Microbiol. Ecol. 17, 85-94 (1995).

7. Whiticar, M. J., Faber, E. \& Schoell, M. Biogenic methane formation in marine and freshwater environments: $\mathrm{CO}_{2}$ reduction vs. acetate fermentation: Isotope evidence. Geochim. Cosmochim. Acta 50, 693-709 (1986).

8. Cooles, G. P., Mackenzie, A. S. \& Parkes, R. J. Non-hydrocarbons of significance in petroleum exploration: Volatile fatty acids and non-hydrocarbon gases. Mineral. Mag. 51, 483-493 (1987).

9. Borgund, A. E. \& Barth, T. Generation of short-chain organic-acids from crude-oil by hydrous pyrolysis. Org. Geochem. 21, 943-952 (1994).

10. Whelan, J. K. et al. Evidence for sulfate-reducing and methane-producing organisms in sediments from Sites 618, 619 and 622. Init. Rep. Deep-Sea Drill. Proj. 96, 767-775 (1986).

11. King, G. M. Measurement of acetate concentrations in marine pore water by using an enzymatic approach. Appl. Environ. Microbiol. 57, 3476-3481 (1991).

12. Dickens, G. R. et al. Direct measurements of in situ methane quantities in a large gas-hydrate reservoir. Nature 385, 426-428 (1997).

13. Cragg, B. A. et al. Bacterial biomass and activity profiles within deep sediment layers. Proc. ODP Sci. Res. 112, 607-619 (1990).

14. Wellsbury, P., Herbert, R. A. \& Parkes, R. J. Bacterial activity and production in near-surface estuarine and freshwater sediments. FEMS Microbiol. Ecol. 19, 203-214 (1996).

15. Paull, C. K. et al. Leg 164-gas hydrate sampling on the Blake Ridge and Carolina Rise. Proc. ODP Init. Rep. 164, 623 (1966).

16. Barth, T. Quantitative determination of volatile carboxylic acids in formation water by isotachophoresis. Anal. Chem. 59, 2232-2237 (1987).

17. Stetter, K. O. Hyperthermophiles in the history of life. Ciba Found. Symp. 202, 1-18 (1996),

18. Cragg, B. A. \& Parkes, R. J. Bacterial profiles in hydrothermally active deep sediment layers from Middle Valley (N.E. Pacific) Sites 857 and 858. Proc. ODP Sci. Res. 139, 509-516 (1993).

19. Haridon, S. L., Reysenbach, A., Glenat, P., Prieur, D. \& Jeanthon, C. Hot subterranean biosphere in continental oil reservoir. Nature 377, 223-224 (1995).

20. Galimov, E. M. \& Kvenvolden, K. A. Concentrations and carbon isotopic compositions of $\mathrm{CH}_{4}$ and $\mathrm{CO}_{2}$ in gas from sediments of the Blake Outer Ridge, Deep-Sea Drilling Project Leg 76. Init. Rep. DeepSea Drill. Proj. 76, 403-407 (1983).

21. de Graaf, W., Wellsbury, P., Parkes, R. J. \& Cappenberg, T. E. Comparison of acetate turnover in methanogenic and sulfate-reducing sediments by radio- and stable-isotope-labeling and specific inhibitors: Evidence for isotopic exchange. Appl. Environ. Microbiol. 62, 772-777 (1996).

22. Cragg, B. A. et al. Bacterial profiles in deep sediments of the Santa Barbara Basin Site 893. Proc. ODP Sci. Res. 146, 139-144 (1995).

23. Cragg, B. A. et al. The impact of fluid and gas venting on bacterial populations and processes in sediments from the Cascadia Margin accretionary system (sites 888-892) and the geochemical consequences. Proc. ODP Sci. Res. 146, 399-411 (1995).

24. Furnes, H., Thorseth, I. H., Tumyr, O., Torsvik, T. \& Fisk, M. R. Microbial activity in the alteration of glass from pillow lavas from Hole 896A. Proc. ODP Sci. Res. 148, 191-214 (1996). 
25. Giovannoni, S. J., Fisk, M. R., Mullins, T. D. \& Furnes, H. Genetic evidence for endolithic microbial life colonising basaltic glass/seawater interfaces. Proc. ODP Sci. Res. 148, 207-214 (1996).

26. Rochelle, P. A., Fry, J. C., Parkes, R. J. \& Weightman, A. J. DNA extraction for $16 \mathrm{~S}$ rRNA gene analysis for determining genetic diversity in deep sediment communities. FEMS Microbiol. Lett. 100, 59-66 (1992).

27. Parkes, R. J. et al. Biogeochemical processes in gas hydrate zones. Abstracts, Exploration and exploitation of non-living deep-sea marine resources. Challenger Society for Marine Science \& Geological Society, Marine Studies Group (Geological Society, London, 1996).

28. Jørgensen, B. B., Isaksen, M. F. \& Jannasch, H. W. Bacterial sulfate reduction above $100^{\circ} \mathrm{C}$ in deep-se hydrothermal sediments. Science 258, 1756-1757 (1992).

29. Parkes, R. J. \& Taylor, J. Analysis of volatile fatty acids by ion-exclusion chromatography, with special reference to marine pore water. Mar. Biol. 77, 113-118 (1983).

Acknowledgements. We thank ODP for allowing us to obtain samples on Leg 164; T. Woodward and I Mather for their assistance with sample collection and initial handling in the laboratory; J. Maxwell, E. Shock and J. Whelan for comments on the original manuscript; P. Egeberg for facilitating analysis of Site 997; M. Isaksen for details of the thermal gradient system, and F. Wheeler for its construction. This work was funded by the European Union Environment Programme and the Natural Environment Research Council (UK)

Correspondence and requests for materials should be addressed to R.J.P. (e-mail: j.parkes@bris.ac.uk).

\section{The fate of carbon in} grasslands under carbon dioxide enrichment

\section{Bruce A. Hungate ${ }^{\star} \uparrow$, Elisabeth A. Holland $\ddagger$, Robert B. Jackson $\$$, F. Stuart Chapin III*, Harold A. Mooney\| \& Christopher B. Fieldg}

${ }^{*}$ Department of Integrative Biology, University of California, Berkeley, California 94720, USA

$\$$ Atmospheric Chemistry Division, National Center for Atmospheric Research, Boulder, Colorado 80307, USA

\| Department of Biological Sciences, Stanford University, Stanford, California 94305, USA

$\S$ Department of Botany, University of Texas at Austin, Austin, Texas 78713, USA g Carnegie Institution of Washington, Department of Plant Biology, Stanford, California 94305, USA

$\dagger$ Present address: Smithsonian Environmental Research Center, Edgewater, Maryland 21037, USA

The concentration of carbon dioxide $\left(\mathrm{CO}_{2}\right)$ in the Earth's atmosphere is rising rapidly ${ }^{1}$, with the potential to alter many ecosystem processes. Elevated $\mathrm{CO}_{2}$ often stimulates photosynthesis ${ }^{2}$, creating the possibility that the terrestrial biosphere will sequester carbon in response to rising atmospheric $\mathrm{CO}_{2}$ concentration, partly offsetting emissions from fossil-fuel combustion, cement manufacture, and deforestation ${ }^{3,4}$. However, the responses of intact ecosystems to elevated $\mathrm{CO}_{2}$ concentration, particularly the below-ground responses, are not well understood. Here we present an annual budget focusing on below-ground carbon cycling for two grassland ecosystems exposed to elevated $\mathrm{CO}_{2}$ concentrations. Three years of experimental $\mathrm{CO}_{2}$ doubling increased ecosystem carbon uptake, but greatly increased carbon partitioning to rapidly cycling carbon pools below ground. This provides an explanation for the imbalance observed in numerous $\mathrm{CO}_{2}$ experiments, where the carbon increment from increased photosynthesis is greater than the increments in ecosystem carbon stocks. The shift in ecosystem carbon partitioning suggests that elevated $\mathrm{CO}_{2}$ concentration causes a greater increase in carbon cycling than in carbon storage in grasslands.

In most ecosystems, leaf and canopy gas-exchange measurements indicate that there is increased carbon uptake in response to experimental doubling of $\mathrm{CO}_{2}$ concentration ${ }^{5,6}$. However, increased carbon uptake in these one- to ten-year experiments does not necessarily indicate a large potential for carbon storage over 50100 years, the predicted timescale of atmospheric $\mathrm{CO}_{2}$ doubling ${ }^{7}$. Ecosystem sequestration of carbon over 50-100 years requires delivery of the extra carbon to large pools with slow turnover (wood and soil organic matter) ${ }^{8}$. However, net gas-exchange measurements do not reveal whether the extra carbon fixed in response to elevated $\mathrm{CO}_{2}$ is distributed to these pools. The partitioning of this extra carbon among pools with varying turnover times is a critical controller of the potential for terrestrial ecosystems to increase long-term carbon storage.

A consequence of $\mathrm{CO}_{2}$-stimulated plant growth may be an increased demand for below-ground resources (water and mineral nutrients). If the demands for below-ground resources are not met by increased resource availability or efficiency of resource use ${ }^{9,10}$, or if growth potential is constrained ${ }^{11}$, plants may increase their loss of carbon through root turnover, respiration or exudation. Carbon allocation to these rapid-turnover pools limits the quantity of longterm carbon storage in response to elevated $\mathrm{CO}_{2}$ because most of the carbon is quickly returned to the atmosphere as $\mathrm{CO}_{2}$ (refs 12,13). Many studies have documented changes in the root biomass of plants grown under elevated $\mathrm{CO}_{2}$ (refs 14, 15), but root turnover, exudation and respiration are difficult to quantify directly for budgets of total carbon partitioning to roots ${ }^{16}$. We have used two indirect approaches to assess carbon partitioning to roots. First, we used a mass balance model to describe the carbon stocks, partitioning and annual carbon fluxes in two annual grasslands in California after three years of exposure to elevated $\mathrm{CO}_{2}$. Second, we used isotope labelling of reconstructed ecosystems exposed to elevated $\mathrm{CO}_{2}$ to measure the partitioning of below-ground carbon fluxes.

Our field experimental system consists of naturally occurring a Sandstone

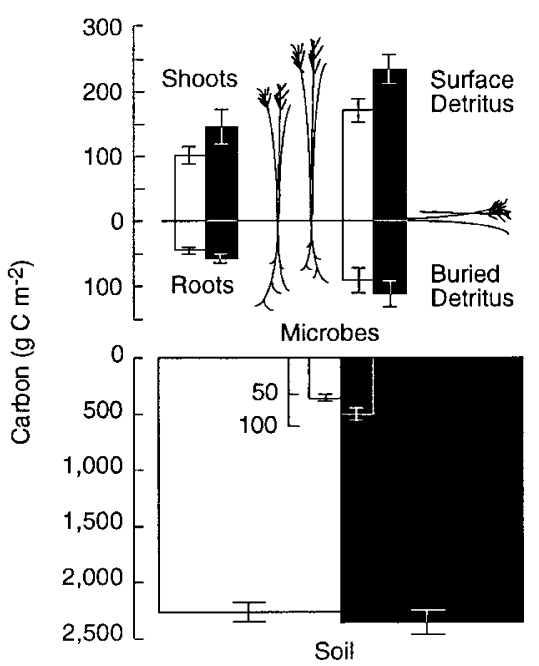

b Serpentine
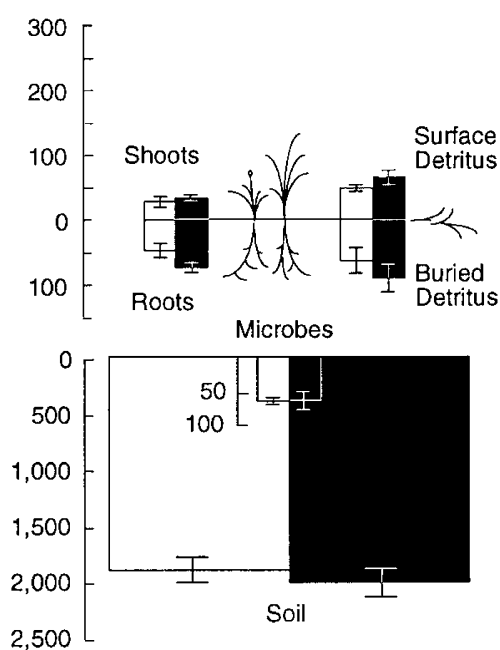

Figure 1 Carbon pools ( $\mathrm{g} \mathrm{C} \mathrm{m}^{-2}$, mean \pm s.e.) at peak biomass in 1994 for sandstone (a) and serpentine (b) grasslands in ambient (open bars) and elevated (filled bars) $\mathrm{CO}_{2}$. 